\title{
PENILAIAN BIMBINGAN KONSELING DI SEKOLAH DAN IMPLIKASI PENGELOLAANNYA
}

\author{
Oleh: Tri Anjar \\ (Program Studi Bimbingan Konseling FKIP Universitas Muhammadiyah Metro)
}

\section{A. PENDAHULUAN}

Sebagaimana telah dijabarkan dalam berbagai makalah sebelumnya, salah satu konsep perencanaan program BK yang baik adalah 'memungkinkannya dilakukan penilaian'. Sejumlah ketentuan dan rumusan tentang tatalaksana bimbingan konseling disetiap jenjang pendidikan pun pada akhirnya akan menyisakan pemikiran dalam benak kita tentang "Bagaimana konsep dan pelaksanaan penilaian terhadap bimbingan konseling itu sendiri ?". Pengelolaan dan pelaksanaan bimbingan konseling yang berorientasi pada pencapaian tujuan belajar dan kegiatan dalam pembelajaran tentunya memerlukan sebuah penilaian, baik sebagai balikan maupun sebagai tahapan manajemenistik yang baik dan sistematis. Penilaian yang dimaksud tentunya akan mengarah kepada apa dan siapa?

Sebelum sampai pada pembicaraan tentang penilaian bimbingan konseling, makalah ini juga akan menyajikan berbagai istilah yang terkait erat dan cenderung bersinonim dengan konteks penilaian seperti istilah pengukuran, assessment, dan evaluasi. Dalam pemahaman keseharian yang universal, pemaknaan terhadap ketiga peristilahan ini mungkin saja sama, akan tetapi secara parsial tetap memiliki perbedaan yang prinsip. Pemisahan yang tepat tentunya akan memberikan pemahaman yang kontekstual dan implisit kita terhadap ketiga peristilahan itu.

Muri Yusuf (2005 : 12-17) menyatakan bahwa pengukuran dalam proses belajar mengajar atau dalam pendidikan merupakan suatu prosedur penerapan angka atau simbol terhadap suatu objek atau kegiatan maupun kejadian sesuai dengan aturan. Sedangkan assessment diartikan sebagai proses pengumpulan informasi yang digunakan untuk mengambil keputusan tentang : kebijakan pendidikan, mutu pendidikan, mutu program pendidikan atau mutu kurikulum, mutu proses pendidikan, mutu input dan produk atau tentang penguasaan peserta didik berkaitan dengan apa yang telah diajarkan padanya. Adapun konsep evaluasi diartikan sebagai suatu proses penggambaran, pemerolehan, dan penyediaan informasi yang berguna untuk penetapan alternatif-alternatif keputusan.

Dengan mengamati ketiga konsep di atas, maka pembahasan tentang penilaian tentu bukanlah suatu konsep yang sederhana dengan hanya memberikan atribut tertentu (kualitatif maupun kuantitatif) semata, akan tetapi merupakan kegiatan yang sistematis dengan memperhatikan berbagai aturan atau prosedur tertentu. Terutama pembicaraan tentang penilaian bimbingan konseling, konsep utama yang mesti disepakati adalah berkenaan dengan pemakaian istilah yang tepat untuk mengukur, mengasesment, mengevaluasi, atau pun menilai bimbingan konseling. Pertanyaan yang dapat kita kaji adalah "Apakah istilah penilaian dalam bimbingan konseling itu merupakan suatu kompilasi dari ketiga konsep tadi?" Makalah ini tidak membahas lebih jauh tentang persoalan di atas, akan tetapi lebih 
mengarah pada pemenuhan kisi yang telah disilabuskan dalam mata kuliah manajemen bimbingan konseling, dengan tetap mengetengahkan istilah penilaian dalam presentasenya. Hasil diskusi dalam khasanah forum ilmiah ini yang kami harapkan dapat muncul sebagai jawaban atas ketepatan atau ketidaktepatan beberapa pertanyaan seputar konsep itu. Keterbatasan dalam memaknai konsep, kepemilikan wawasan, dan minimnya literatur dalam membangun makalah ini juga merupakan hal yang tidak terpungkiri untuk diperbaiki penyaji dimasa yang akan datang.

Dasar utama dalam mengetengahkan pembahasan tentang penilaian ini bertolak dari pancandraan terhadap UUSPN Nomor 20 tahun 2003 dan Permendiknas No. 19/ 2007 tentang standart pengelolaan pendidikan dan Permendiknas No. 20/2007 tentang standart penilaian. Konsep penilaian ini juga berpijak pada kebijakan KTSP dalam mencitakan ketercapaian tujuan pendidikan nasional yang implikasinya meminta guru pembimbing untuk terlibat secara aktif dan sistematis sebagai bagian yang integral dari proses pendidikan anak di sekolah melalui kegiatan pengembangan diri. Bahasan tentang penilaian bimbingan konseling ini juga akan diarahkan dengan pendekatan KTSP.

\section{B. BEBERAPA KONSEP DASAR DALAM PENILAIAN BIMBINGAN KONSELING}

\section{Konsep Penilaian}

Berdasarkan Permendinas No.20 tahun 2007, konsep tentang penilaian dijabarkan sebagai "proses pengumpulan dan pengolahan informasi untuk menentukan pencapaian hasil belajar peserta didik". Dalam pengertian ini, penilaian merupakan suatu kegiatan yang memiliki tahapan tertentu (berproses : mekanisme, prosedur, dan instrument yang digunakan), dengan mengetengahkan pengumpulan dan pengolahan akan berbagai informasi. Lalu, informasi apa saja yang akan dikumpulkan dan diolah ? Bagaimanakah bentuk atau atribut yang mengindikasikan pencapaian hasil belajar itu? Informasi yang dimaksud tentu berkaitan dengan objek yang dinilai, baik tentang siswa dengan semua kompetensi yang dimilikinya (sebagai intervensi pembelajaran/bimbingan), maupun tentang seperangkat unsur yang mendukung untuk ketercapaian itu (program pembelajaran/ program bimbingan konseling).

Informasi yang dikumpul untuk diolah itu dapat berkenaan dengan kemampuan belajar (kognitif), keterampilan yang telah diperoleh (psikomotor), atau kesesuaian sikap yang diinginkan (afektif). Informasi ini akan diolah berdasarkan mekanisme tertentu untuk sampai pada keputusan yang mendeskripsikan suatu objek tersebut. Deskripsi itu dapat dilambangkan dengan nilai-nilai maupun dilambangkan dengan atribut lain. Deskripsi inilah yang kemudian dapat ditafsirkan sebagai bentuk hasil belajar. Penjabaran ini sekaligus mengetengahkan pemahaman bahwa kegiatan penilaian itu merupakan komposisi dari kegiatan mengukur, mengasessment, dan mengevaluasi. Namun, mengingat kedudukan bimbingan konseling dalam aplikasi tugasnya bukan berfungsi sebagai pemberi nilai yang sifatnya formil seperti guru bidang studi, maka istilah penilaian dalam khasanah bimbingan konseling akan lebih tepat jika ditekankan pada konsep evaluasi.

Dalam pengertian ini, Muri (2005: 16) menyatakan bahwa evaluasi adalah proses penggambaran, pemerolehan, dan penyediaan informasi yang berguna untuk penetapan alternatif-alternatif keputusan. 
Informasi (kualitatif/kuantitatif) yang digunakan sebagai penggambaran ini sebelumnya telah melewati prosedur pengukuran dan assesment dengan menggunakan instrumen (tes dan non tes) berdasarkan patokan yang telah disepakati (standart penilaian). Masih menurut Muri (2005: 3), evaluasi pada runtutnya akan memberikan pertimbangan (judgement), nilai (value), dan arti (worth) terhadap semua komponen yang berkenaan dengan proses pelaksanaan dan produk pendidikan secara total.
Dalam khasanah KTSP, dengan mengedepankan kerangka model pengembangan diri yang terdiri atas peranan bimbingan konseling dalam pengembangan diri, perumusan kompetensi/sasaran pengembangan diri, kegiatan pengembangan diri, dan pengelolaan pelayanan pengembangan diri, konsep penilaian bimbingan konseling tentunya akan memiliki corak tersendiri dan berfokus pada ketercapaian visi dan misi bimbingan konseling. Dalam konteks ini, kedudukan penilaian bimbingan konseling dapat dilihat pada bagan dibawah ini :

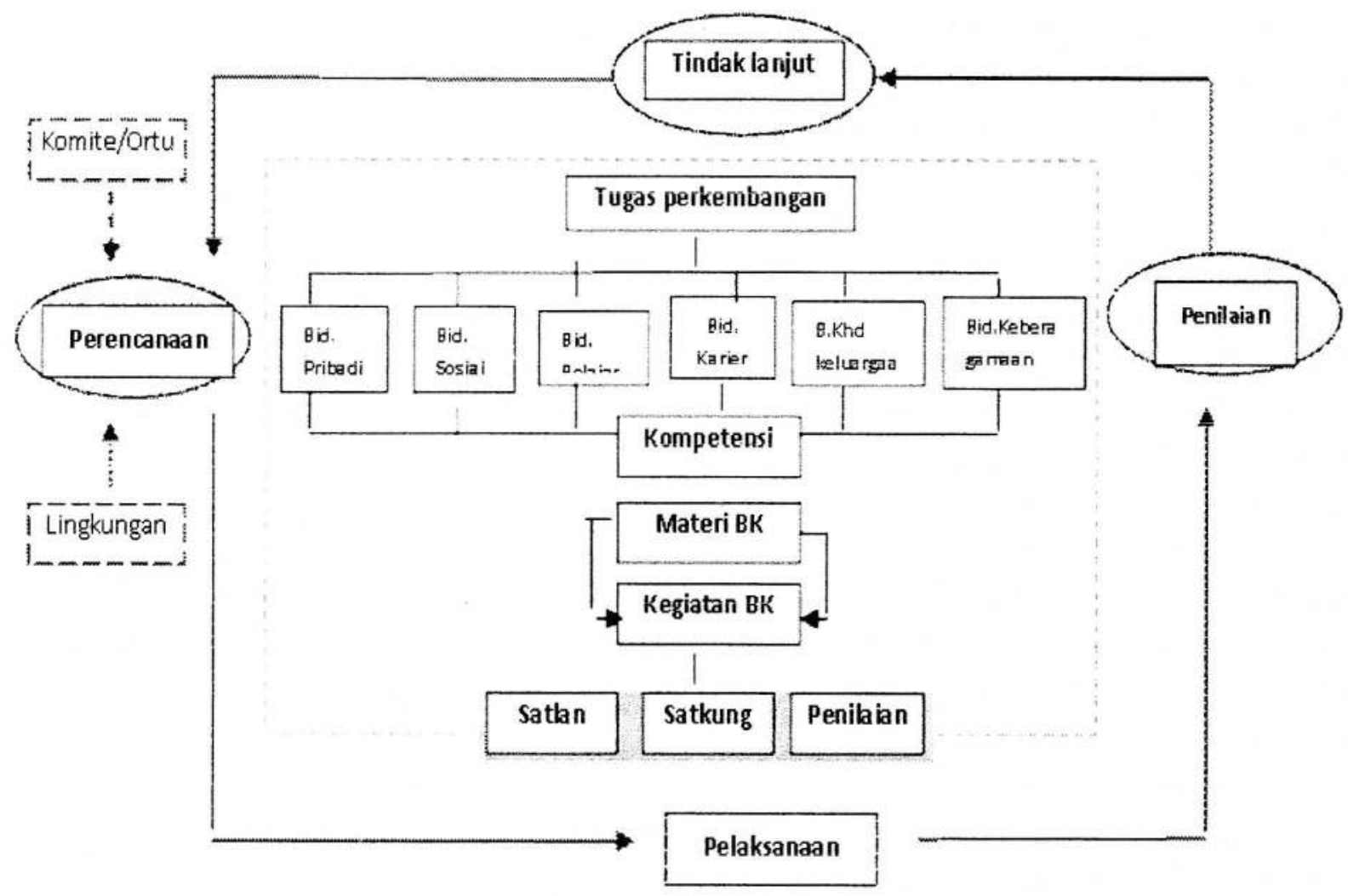

Bagan di atas menggambarkan bahwa konsep evaluasi bimbingan konseling dalam KTSP merupakan kegiatan yang berkesenambungan dan terkait satu sama lainnya meliputi kegiatan dalam perencanaan, pelaksanaan, penilaian, dan tindak lanjut. Asesment dalam setiap kegiatan itu akan memberikan berbagai informasi sebagai tujuan dalam penentuan berbagai alternatif keputusan. Evaluasi

dalam keterkaitan bimbingan konseling juga merupakan penggambaran terhadap bimbingan konseling yang akan melahirkan berbagai keputusan baik terhadap bimbingan konseling, guru pembimbing, maupun terhadap program kerja dan layanan itu sendiri.

Karenanya, evaluasi dalam bimbingan itu hendaknya meliputi berbagai arah evaluasi antara lain (1) evaluasi context, yaitu 
berkenaan dengan kebijakan (2) evaluasi input, berkenaan dengan peserta didik, sarana prasarana, program, dan input lingkungan, (3) evaluasi proses, yang berkenaan dengan pemberdayaan atau pendayagunaan bimbingan terhadap warga sekolah, (4) evaluasi hasil, berkenaan dengan penguasaan, pemahaman, dan keterampilan atau kemajuan yang telah dialami siswa terhadap tujuan atau nilai yang telah ditetapkan dalam program, dan (5) evaluasi outcomes (dampak), yang berkenaan dengan dampak hasil terhadap kehidupan diluar situasi pendidikan atau dalam kehidupan dimasa akan datang (Muri, 2005. hal 3-4).

Berdasarkan kelima arah evaluasi tersebut, kegiatan penilaian akan diformulasikan berdasarkan model-model penilaiannya. Model atau pendekatan yang digunakan dalam kegiatan penilaian akan memberikan hierarki prosedur yang sistematis terhadap arah dan maksud penilaian. Melalui pendekatan/model penilaian itu pula, kegiatan penilaian akan mencapai tujuan yang sesuai dengan kebutuhan informasi yang spesifik dan objektif tentang apa-apa yang ingin dideskripsikan.

Salah satu model yang dapat digunakan dalam kegiatan penilaian adalah model penilaian Stufflebeam's yang terdiri atas empat kategori penilaian yaitu :

evaluasi konteks yakni berkaitan dengan penyediaan informasi dan penetapan tujuan yang baik, lingkungan yang relevan, dan identifikasi masalah yang berhubungan dengan program atau kegiatan, (2) evaluasi input yakni berkaitan dengan penentuan memanfaatkan input dalam mencapai tujuan, (3) evaluasi proses yakni berkaitan dengan pemberian umpan balik secara periodik dalam pelaksanaan program, dan (4) evaluasi hasil yakni berkaitan dengan pengukuran pencapaian tujuan yang telah ditetapkan sebelumnya (Muri, 2005. hal 3942).

Perlu diingat, bahwa pendekatan yang digunakan dalam penilaian hendaknya tidak digunakan hanya pada satu aspek atau satu model saja, akan tetapi diperlukan kombinasi yang beragam, sehingga tujuan yang ingin dicapai dari penilaian tidak bias. Jika model penilaian Stufflebeam's ini kita adopsikan untuk membangun kerangka penilaian tentang bimbingan konseling, maka jenis penilaiannya akan terdiri minimal tiga kategori/jenis yaitu : (1) penilaian program bimbingan yang meliputi evaluasi konteks dan evaluasi input, dan (2) penilaian proses kegiatan bimbingan meliputi evaluasi proses layanan dan (3) penilaian hasil layanan meliputi evaluasi hasil layanan.

Penilaian ini pada akhirnya akan direfleksikan secara seksama dan akan bermuara pada berbagai prosedur dan kriteria ketetapan misalnya pada standart pengelolaan satuan pendidikan (Permendiknas No.19/2007), standart sarana prasarana (Permendiknas No. 24/2007), standar isi (Permendiknas No. 22/2006), standar kompetensi lulusan (Permendiknas No. 23/2006), standart penilaian (Permendiknas No. 20/2007), kepengawasan (Permendiknas No. 12/ 2007), dan sejumlah ketetapan lainnya.

Lebih jauh tentang konsep penilaian sebagaimana disampaikan diawal pembahasan di atas, mengenai apa yang akan dinilai dan siapa yang akan menilai bimbingan konseling itu? Pertanyaan ini mengintegrasikan dua kategori jawaban pula, yakni berkenaan dengan objek yang akan dinilai (komponen bimbingan : peserta didik, program, sarana, prasarana, media, alat, proses, lingkungan belajar,dan hasil) serta subjek penilai atau evaluator (personil jabatan) yang akan memberikan penilaian. 
Jika pertanyaan pertama telah sedikit disinggung dalam bahasan di atas, maka pertanyaan kedua akan menandaskan tentang kemungkinan terdapatnya beberapa personil yang ikut terlibat secara fungsional dan memiliki legalitas konstitusional untuk melakukan kegiatan penilaian terhadap bimbingan konseling. Selain itu, konsep penilaian dalam bimbingan konseling dijalankan pada permulaan kegiatan bimbingan, pada saat pelaksanaan program, dan diakhir pelaksanaan kegiatan bimbingan, dimulai dari rencana program, pelaksanaan layanan, sampai pada hasil layanan.

Personil-personil yang dimaksud dapat berupa pengawas sekolah, kepala sekolah, dan guru pembimbing itu sendiri. Pengawas dan kepala sekolah akan menggeneralisir kegiatan pengawasan terhadap program kegiatan BK dan kinerja guru pembimbing, sementara guru pembimbing berkedudukan sebagai penilai (subjek) satuan layanan sekaligus sebagai objek yang dinilai.

\section{Tujuan Penilaian}

Kegiatan penilaian pada hakikatnya bertujuan untuk mengetahui atau memperoleh gambaran yang bersifat informasi akurat tentang keefektifan dan efisiensi sesuatu yang telah dilaksanakankan. Informasi berkenaan dengan keefektifan dan keefisiensian ini selanjutnya akan melahirkan suatu keputusan tertentu. Secara khusus tujuan penilaian akan sangat ditentukan oleh fungsi penilaian (pengambilan keputusan dan penyediaan informasi) dan aspek-aspek yang akan dinilai itu sendiri. Misalnya penilaian yang ditujukan untuk program bimbingan konseling, akan memfungsikan kegiatannya pada penyediaan sejumlah informasi tentang program itu dan seterusnya akan pula melahirkan keputusan tentang keefektifan atau efisiensi program,dan seterusnya.

Penilaian juga dimaksudkan untuk mengetahui seberapa jauh kompetensi yang diharapkan telah dimiliki peserta didik. Untuk itu setiap akhir pemberian layanan diperlukan adanya feedback (umpan balik) untuk mengetahui keberhasilan layanan yang diberikan dengan mengetahui apakah kompetensi yang diharapkan dari materi yang diberikan sudah dimiliki oleh peserta didik. Dengan demikian maka yang perlu diketahui adalah kondisi nyata keadaaan peserta didik terkait dengan materi layanan yang diberikan.

Sasaran penilaian bimbingan dan konseling berorientasi pada perubahan tingkah laku (termasuk di dalamnya pendapat, nilai, dan sikap) serta perkembangan siswa. Oleh karena itu penilaian dilakukan dalam proses pencapaian kemajuan perubahan tingkah laku dan perkembangan siswa tersebut.

Selain itu tujuan penilaian akan sangat bergantung pada pendekatan atau model penilaian yang digunakan. Misalnya, pada model penilaian Stufflebeam's Model yang terdiri atas empat kategori tadi, penilaian akan memunculkan empat tujuan penilaian pula. Begitu pula dengan Stufflebeam's Model dalam kerangka bangun penilaian bimbingan konseling yang terdiri dari tiga kategori (program, proses, dan hasil), juga akan melahirkan tiga pokok tujuan.

Dengan kategori ini, tujuan yang dapat dicapai berkaitan dengan penilaian program menurut Cronbach dalam Furqon (2005: 2) akan bermanfaat untuk membantu meningkatkan program tersebut. Sementara Patton mengemukan dua manfaat kegiatan penilaian program yaitu (1) memberikan kepastian dan keyakianan tentang program yang terlaksana dan (2) mendapatkan informasi yang lebih sempurna. Adapun 
Anderson dan Ball (Furqon,2005: 3) menyebutkan bahwa tujuan penilaian program adalah:

" Memberikan kontribusi dalam pengambilan keputusan tentang instalasi program.

" Memberikan kontribusi dalam pengambilan keputusan tentang keberlanjutan, ekspansi atau sertifikasi program

" Memberikan kontribusi dalam pengambilan keputusan tentang modifikasi program

" Menyediakan bukti dukungan positif terhadap program

" Menyediakan bukti dukungan negatif terhadap suatu program

" Memberikan kontribusi dalam memahami dasar yang bersifat psikologis, sosial dam proses lainnya.

Chelimsky dalam Furqan (2005: 3) menyatakan bahwa penilaian program bertujuan untuk menegakkan akuntabilitas (Evaluation for accountability), mengembangkan program yang ada (Evaluation for development), dan menambah dan memperkaya pengetahuan (Evaluation for Knowledge).

Penilaian Proses Kegiatan bertujuan untuk mengetahui sejauhmana pencapaian rumusan kegiatan yang telah diprogramkan dalam satuan-satuan layanan dapat diimplementasikan kepada sasaran layanan, sehingga tersedia informasi tentang kualitas atau mutu layanan. Sedangkan Penilaian Hasil Layanan bimbingan konseling bertujuan untuk mengetahui tingkat ketercapaian kompetensi-kompetensi yang diberikan dalam materi bimbingan konseling.

Prayitno ( 2006 ) menyatakan bahwa Penilaian bimbingan dan konseling ditujukan kepada penilaian dalam proses yang dapat dilakukan dengan :

a. Mengamati partisipasi dan aktivitas siswa dalam kegiatan layanan

b. Mengungkapkan pemahaman siswa atas materi yang disajikan atau pemahaman atas masalah yang dialaminya.

c. Mengungkapkan kegunaan layanan dan mengamati perkembangan siswa.

d. Mengungkapkan kelancaran proses dan suasana penyelenggaraan kegiatan layanan.

\section{Asas-Asas Penilaian}

Masih merujuk pada lampiran Permendiknas nomor 20 point $\mathrm{B}$ tentang prinsip penilaian hasil belajar, maka asas yang diperhatikan dalam menyusun mekanisme dan prosedur penilaian bimbingan konseling hendaknya didasarkan pada asas-asas sebagai berikut:

a. sahih, berarti penilaian didasarkan pada data yang mencerminkan kemampuan yang diukur.

b. objektif, berarti penilaian didasarkan pada prosedur dan kriteria yang jelas, tidak dipengaruhi subjektivitas penilai.

c. adil, berarti penilaian tidak menguntungkan atau merugikan peserta didik karena berkebutuhan khusus serta perbedaan latar belakang agama, suku, budaya, adat istiadat, status sosial ekonomi, dan gender.

d. terpadu, berarti penilaian oleh pendidik merupakan salah satu komponen yang tak terpisahkan dari kegiatan pembelajaran.

e. terbuka, berarti prosedur penilaian, kriteria penilaian, dan dasar pengambilan keputusan dapat diketahui oleh pihak yang berkepentingan.

f. menyeluruh dan berkesinambungan, berarti penilaian oleh pendidik mencakup semua aspek kompetensi 
dengan menggunakan berbagai teknik penilaian yang sesuai, untuk memantau perkembangan kemampuan peserta didik.

g. sistematis, berarti penilaian dilakukan secara berencana dan bertahap dengan mengikuti langkah-langkah baku.

h. beracuan kriteria, berarti penilaian didasarkan pada ukuran pencapaian kompetensi yang ditetapkan.

i. akuntabel, berarti penilaian dapat dipertanggungjawabkan, baik dari segi teknik, prosedur, maupun hasilnya.(Muri, 2005)

\section{Tahap-Tahap dan Jenis Penilaian}

Mencermati berbagai konsep tentang evaluasi dalam pendidikan, maka tahaptahap penilaian dalam bimbingan konseling dapat dikembangkan dengan terlebih dahulu menentukan tujuan penilaian. Tujuan penilaian akan mengantarkan kegiatan menilai pada pemilihan model/pendekatan yang akan digunakan. Setiap model akan mengetengahkan formula yang berbeda, baik dari segi prosedur, teknik, sistematika (cara pelaksanaan, pengadministrasian, dan tindak lanjut penilaian), maupun jenis instrument yang digunakan. Pemilihan model penilaian yang tepat akan memungkinkan kegiatan penilaian bermuara pada tujuan yang diinginkan.

Langkah-langkah dalam penilaian dapat berupa : (1) mengenali tujuan penilaian dan keputusan yang akan diambil, (2) menentukan siapa yag akan mengambil keputusan, (3) menetapakan kriteria penilaian, (4) menentukan sumber data, (5) menentukan cara pengumpulan data (6) mengumpulkan data, (7) menganalisa data, (8) menafsirkan data dan melaporkan hasil, (9) mengambil keputusan mengenai program berdasarkan simpulan penilaian.

Adapun jenis penilaian dalam bimbingan konseling dapat dikategorikan dalam dua bentuk yaitu :

\section{a. Penilaian Program Bimbingan Konseling}

Penilaian program dimaksudkan untuk memperoleh informasi yang valid dan reliabel tentang keefektifan dan efiesiensi program. Muri (2005:162) menyatakan bahwa evaluasi program berdimensi ganda, yakni tertuju pada program sebagai dokumen tertulis dan disatu sisi tertuju pada pelaksanaan dan hasil program. Tahap penilaian program diarahkan pada rencana program, pelaksanaan program, dan hasil yang dicapai. Karenanya, penilaian dapat berbentuk evaluasi rencana, evaluasi pelaksanaan, dan evaluasi hasil program. Model dan instrument dalam penilaian program dapat didekati dengan pendekatan kualitatif baik menggunakan teknik interviu/ wawancara dengan tim pengembang, atau instrument dengan menggunakan kuesioner/ angket untuk hal-hal umum dan spesifik yang dapat didalami melalui pertanyaan 'probing". Sedangkan pelaksanaannya dapat diamati dengan interviu dan observasi, berkenaan dengan manfaat, relevansi, dan dampak yang dapat dilakukan dengan berkomunikasi langsung dengan peserta didik yang pernah mengikuti kegiatan tersebut. Dengan melakukan cost-benefit analysis terhadap program, akan diperoleh informasi yang berguna untuk memutuskan kelayakan program tersebut untuk dilanjutkan, diperbaiki, atau dihentikan (Muri, 2005. hal 163-164). 
Skema arah dan putaran evaluasi :

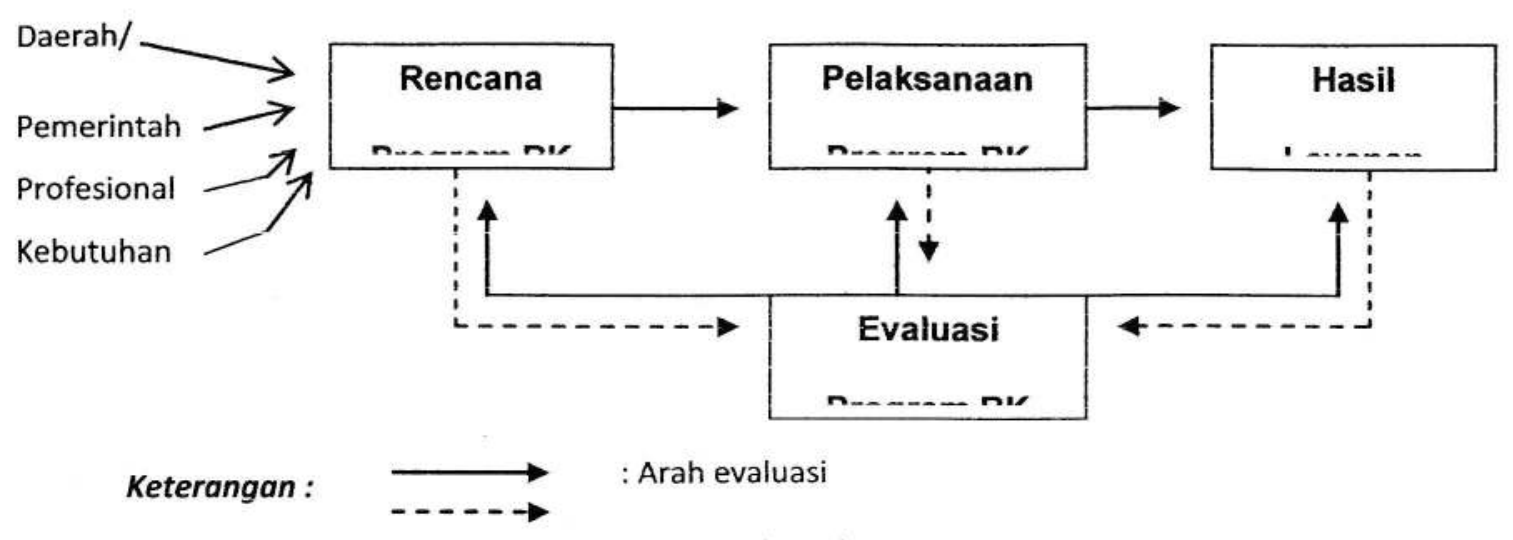

\section{b. Penilaian Proses Kegiatan Bimbingan Konseling}

Penilaian proses bimbingan konseling dimaksudkan untuk mengetahui sejauh mana pencapaian rumusan kegiatan yang telah diprogramkan dalam satuan-satuan layanan dapat diimplementasikan kepada sasaran layanan, sehingga tersedia informasi tentang kualitas atau mutu layanan. Evaluasi proses dimaksud untuk memberikan umpan balik secara periodik dalam pelaksanaan program. Di samping itu, untuk mengontrol prosedur dan rencana yang telah disusun. Dengan cara demikian dapat mendeteksi atau meramalkan segala sesuatu yang mungkin terjadi selama program itu dilaksanakan.

Menurut W.S. Winkel penilaian dalam konteks ini dapat bersifat formal dan informal. Penilaian formal mencakup suatu penelitian sistematis dan ilmiah, berdasarkan suatu desain dan dengan menggunakan metode serta alat tertentu. Evaluasi formal berusaha menentukan apakah rangkaian kegiatan bimbingan sesuai rencana program yang telah ditetapkan untuk mencapai tujuan konkret tertentu telah mencapai efek-efek yang diharapkan.

Intervensi bimbingan dan konseling mempunyai dampak substansial terhadap perkembangan pribadi dan pendidikan siswa. Selanjutnya dilihat dari segi perolehan siswa dari layanan bimbingan konseling dapat dilakukan penilaian dengan tahap-tahap penilaian : 1) segera 2) jangka pendek 3) jangka panjang. Sedangkan untuk penilaian aspek lain dapat digunakan daftar isian, angket atau instrumen lainnya. Dalam pemilihan bentuk dan tipe instrumen terkait pada apa yang akan diungkapkan melalui layanan tersebut, dan kemampuan guru pembimbing dalam menghayati dan menyusun instrumen tersebut.

Penilaian segera adalah penilaian yang dilakukan menjelang proses layanan berakhir. Penilaian bentuk ini dimaksudkan diperolehnya wawasan/pengetahuan baru, perasaan positif dan perencanaan kegiatan yang akan dilakukan klien setelah selesainya layanan.

Penilaian Jangka pendek adalah penilaian setelah beberapa hari berlangsungnya kegiatan. Penilaian jangka pendek dan jangka panjang adalah penilaian yang dilakukan dakam kurun waktu tertentu ( misalnya satu bulan, satu semester, satu tahu) dan satu unit layanan selesai

Dalam kegiatan pengembangan diri, tujuan umum dan tujuan khusus bimbingan konseling akan dijabarkan dalam rumusan kompetensi yang termuat dalam materi bimbingan. Arah penilaian dalam proses pelaksanaannya menurut Prayitno (1996;24) dapat dilakukan dengan:

1) mengamati partisipasi dan aktivitas siswa dalam kegiatan layanan

2) mengungkapkan pemahaman siswa atas bahan-bahan yang disajikan atau pemahaman/pendalaman siswa atas masalah yang dialaminya. 
3) mengungkapakan kegunaan layanan bagi siswa sebagai hasil dari partisipasi dan aktifitas dalam kegiatan layanan

4) mengungkapkan minat siswa tentang perlunya layanan tindak lanjut

5) mengamati perkembangan siswa dari waktu ke waktu (butir ini terutama dilakukan dalam kegiatan layanan yang berkesinambungan), dan

6) mengungkapkan kelancaran dan suasana penyelenggaraan kegiatan layanan.

Penilaian proses kegiatan bimbingan konseling juga dilakukan terhadap kegiatan layanan, kegiatan pendukung, mekanisme dan isntrumentasi yang digunakan dalam kegiatan, dan pengelolaan dan administrasi kegiatan. Hasil penilaian proses digunakan untuk meningkatkan kualitas kegiatan bimbingan dan konseling secara menyeluruh.

\section{c. Penilaian Hasil Layanan Bimbingan Konseling}

Penilaian hasil dilakukan pada akhir suatu program atau kegiatan. Evaluasi ini dimaksudkan untuk mengukur pencapaian tujuan yang telah ditetapkan dalam kompetensi-kompetensi, berdasarkan standar atau kriteria tertentu.

Menurut Prayitno (1996: 24), sasaran penilaian bimbingan konseling berorientasi pada perubahan tingkah laku (termasuk didalamnya nilai dan sikap) serta perkembangan siswa, oleh karena itu penilaian bimbingan konseling tidak dapat dilakukan melalui ulangan, pemeriksaan hasil pekerjaan rumah, tes maupun ujian, melainkan dilakukan dalam proses pencapaian kemajuan perubahan tingkah lau dan perkembangan siswa itu sendiri. Penilaian hasil layanan dapat dilakukan dengan pendekatan LIRAUSAH yaitu lima ranah penguasaan yaitu : Wawasan dasar menyeluruh (Wadasruh), Komponen yang terlibat (kombat), Lapangan kejadian (Lapjadi), Standar prosedur operisional (SPO), dan Penilaian laporan (PenLap).

\section{Bentuk Hasil penilaian Bimbingan Konseling}

Prayitno dkk, (2002: 26), menyatakan bahwa penilaian hasil layanan ditujukan pada perolehan siswa yang menjalani pelayanan bimbingan dan konseling. Perolehan ini diorientasikan pada tingkat pengentasan masalah klien dan perkembangan aspekaspek kepribadian siswa. Karenanya, fokus penilaian dapat diarahkan pada berkembangnya :

" Pemahaman baru yang diperoleh melalui layanan, dalam kaitannya dengan masalah yang dibahas.

" Perasaan positif sebagai dampak dari proses dan materi yang diberikan melalui layanan.

" Rencana kegiatan yang akan dilaksanakan oleh siswa pasca layanan daiam rangka mewujudkan upaya pengentasan masalah yang dialaminya

Adapun macam-macam penilaian hasil layanan dapat berupa :

1) penilaian segera (Laiseg) yaitu penilaian yang dilakukan sesegera mungkin setelah/saat layanan diberikan. Bentuknya dapat berupa observasi atau pengamatan langsung

2) penilaian jangka pendek (Laijapen)

3) penilaian jangka panjang (Laijapang).

Mengingat dalam pelaksanaan kegiatan bimbingan konseling itu akan memungkinkan dilakukannya kegiatan layanan pendukung, maka penilaian layanan pendukung ini tentunya mempunyai ciri dan kateristik yang berbeda pula. Penilaian kegiatan pendukung akan disesuaikan dengan jenis kegaiatan itu sendiri. Kegiatan pendukung yang dilakukan dengan pendekatan tes akan membawa penilaian berupa kuantitatif, sedangkan kegaiatn pendukung yang dilakukan dengan pendekatan non tes akan bersifat kualitatif. 


\section{IMPLIKASI PENGELOLAAN PENILAIAN}

1. Implikasi Pengelolaan Penilaian terhadap Kegiatan Bimbingan

Esensi yang paling penting dari tujuan-tujuan penilaian bimbingan konseling itu hendaknya mengarah pada visi dan misi bimbingan konseling itu sendiri. Visi yang dimaksud adalah "terwujudnya perkembangan diri dan kemandirian secara optimal dengan hakekat kemanusiaannya sebagai hamba Tuhan YME, sebagai makhluk individu, dan makhluk sosial dalam berhubungan dengan manusia dan alam semesta". Sedangkan Misi bimbingan konseling adalah untuk menunjang perkembangan diri dan kemandirian siswa untuk dapat menjalani kehidupannya sehari-hari sebagai siswa secara efektif, kreatif, dan dinamis serta memiliki kecakapan hidup untuk masa depan karir dalam : (1) Beriman dan bertaqwa terhadap Tuhan YME, (2) Pemahaman perkembangan diri dan lingkungan, (3) Perwujudan diri ke arah dimensi spiritual, (4) Pengambilan keputusan berdasarkan IQ, EQ, dan SQ, dan (5) Pengaktualisasian diri secara optimal.

\section{Masalah dan Solusi}

Masalah :

1. Guru pembimbing belum menerapkan konsep penilaian secara tepat, efektif, dan optimal.

2. Belum tersedianya acuan baku dalam penilaian.

3. Tim penilai masih terdapat personil yang tidak berlatar belakang BK.

4. Dan lain-lain.

Solusi :

1. Hendaknya Guru pembimbing menerapkan konsep penilaian secara tepat, efektif, dan optimal.

2. Merancang acuan penilaian yang sesuai.

3. Pemerintah memibuat kebijakan untuk syarat- syarat pemenuhan sebagai tim penilaian BK di sekolah.

4. Diknas pendidikan hendaknya memperhatikan dan mempertimbangkan basic pendidikan personil tim penilai.

5. Dan lain-lain.

\section{DAFTAR PUSTAKA}

A. Muri Yusuf. 2000. Akuntabilitas Bimbingan dan Konseling, Makalah FIP UNP

.2005. Evaluasi Pendidikan, Padang : UNP

Abdul Qhofur, Pedoman Umum Pengembangan Silabus dan Sistem Penilaian, Jakarta : Dikmenum, Ditjen Dikdasmen, 2003

Badrun Kartowagiran, Pedoman Khusus Pengembangan Instrumen dan Penilaian Ranah Psikomotor, Jakarta : Dikmenum, Ditjen Dikdasmen, 2004.

Djemari Mardapi, Pedoman Khusus Pengembangan Instrumen dan Penilaian Ranah Afektif, Jakarta : Dikmenum, Ditjen Dikdasmen, 2004.

Djemari Mardapi, dkk. Pedoman Umum Pengembangan Silabus, Jakarta : Dikmenum, Ditjen Dikdasmen, 2003.

Furqon. 2005. Kecenderungan Baru dalam Evaluasi Program Bimbingan dan Konseling, Makalah disajikan pada Konvensi Nasional XIV dan Kongres Nasional X ABKIN, ABKIN dan UNNES, Semarang 16 April 2005

Munandir, (tt), Program Bimbingan Karir Di Sekolah, Jakarta : Dirjen PT. Depdikbud.

Prayitno.1996. Seri Pemandu Pelayanan Bimbingan dan Konseling, Jakarta : Ikrar Mandiri Abadi

.Dkk. 2002. Panduan Pelayanan Bimbingan dan Konseling Berbasis Kompetensi, Jakarta: Pusat Kurikulum Balitbang Depdiknas. , 2004. Layanan Profesional

Bimbingan dan Konseling, Jakarta : Puskur Balitbangdiknas. 2009. Wawasan Profesional Konseling, Padang : UNP Press 